\title{
ECOS DA CIÊNCIA DIANTE DOS DESAFIOS CONTEMPORÂNEOS DA SAÚDE
}

Nossa premissa é irrefutável: o mundo vive a maior crise sanitária deste século. A reconhecida conjuntura política e econômica alinhada à defesa intransigente do capital tem desencadeado políticas de austeridade fiscal que demandam um posicionamento de cidadãos, gestores, pesquisadores e trabalhadores.

Embora recente, a COVID-19 (do inglês Coronavirus Disease 2019), doença infeciosa causada pelo novo coronavírus (SARS-CoV-2), reforça a contraposição entre viver e reinventar-se. E traz consigo situações inimagináveis, como a quase inexistência de informações e de conhecimento sobre: a) sua determinação; b) seu desenvolvimento; e c) suas consequências. Isso coloca todos nós diante de uma situação para a qual não haverá solução rápida - enquanto isso, o novo coronavírus exibe dia após dia um poder de disseminação espacial e transmissibilidade poucas vezes visto pela humanidade.

Ademais, a atual quarentena de proporção global expõe uma contradição: Como a humanidade pode evoluir tecnologicamente sem alcançar, com a mesma velocidade, a reinvenção dos próprios seres vivos? Essa doença, para a qual o mundo não estava preparado, evidenciou a fragilidade econômica e social vivenciada pelo ser humano no século XXI tão rapidamente quanto o novo coronavírus se impôs no espaço global.

Nesse diapasão, a ciência, tão questionada, deturpada e desprestigiada, foi chamada a dar sua resposta a complexo contexto determinado pela atual pandemia de COVID-19. Difundir conhecimento é uma função estratégica inerente aos periódicos científicos e tal esforço tem sido empreendido por várias publicações nacionais - que abrem chamadas específicas para estudos relacionados ao tema ou dão maior celeridade aos seus processos de publicação de artigos. Assim, é crucial realçar que a dinamicidade do processo saúde-doença tende a persistir para além da COVID-19.

Este ano de 2020 desafia a ciência a produzir novos conhecimentos, a curto, médio e longo prazo, diante do potencial destrutivo de um vírus que se configura como um fenômeno de impacto biológico, econômico e social que transcende qualquer concepção unidisciplinar de saúde. Tal contexto de múltipla determinação requer tanto o seguimento das pesquisas em desenvolvimento quanto dispositivos de difusão capazes de expôlas com eficiência à crítica científica e à tomada de decisão por parte dos gestores públicos.

É com essa compreensão e com esse compromisso ético-sanitário que a SANARE - Revista de Políticas Públicas, desprendendo-se de qualquer concepção setorializada de ciência e saúde e reconhecendo a necessidade de divulgar novos estudos sobre a pandemia em curso, convida a comunidade científica e o público leitor a se engajarem nessa luta.

Com a consciência de que persistem as precárias condições pré-pandemia que pautam o processo saúde-doença e de que a tendência é que elas sejam agravadas, diante da necessidade de isolamento social, da precarização das condições de trabalho e da queda de renda da população, o número 1 de 2020 da SANARE vem a lume com estudos que revelam nuances de tais fatores em um contexto político, econômico e social e buscam a construção de uma sociedade mais igualitária, solidária e saudável. Os artigos aprovados para esta edição dialogam com as necessidades de amplo espectro vivenciadas pelos territórios brasileiros, em nível nacional e local, e abrangem variados temas no âmbito da Saúde Coletiva.

Certificação de redação científica: E.L.Freire Editora. Edição de texto: Evandro L. Freire. Preparação de original: Dida Bessana. 
Outrossim, a SANARE busca inquietar a comunidade científica diante das novas perspectivas dos pesquisadores sobre a pandemia, em suas múltiplas dimensões, e coloca-se à disposição para acolher seus resultados de pesquisa e analisá-los entre pares, com celeridade, com vistas a divulgá-los em nossa próxima edição. Tudo isso sem deixar de manter-se atenta às necessidades do campo da Saúde Pública e das Políticas Públicas inerentes a ele - que constituem o escopo deste periódico científico com 20 anos de história.

Desejamos muita coragem, muita harmonia entre a humanidade e o espaço global e muita saúde para fazermos esta travessia rumo a um futuro melhor!

Profa. Dra. Maria Socorro de Araújo Dias

Editora Chefe da SANARE - Revista de Políticas Públicas

Diretora da Escola de Saúde Pública Visconde de Saboia 